\title{
Correlation between cephalic circumference at birth and ocular alterations in patients with microcephaly potentially associated with Zika Virus infection
}

\author{
(D) Silvana Aranha Trigueiro \\ (iD) Bárbara Freitas Neves ${ }^{2}$ \\ Michelle Salles Barros de Aguiar ${ }^{3}$ \\ (iD) Juliana Sousa Soares de Araújo ${ }^{4}$
}

1. Masters; Ophthalmologist at the Cândida Vargas Maternity, João Pessoa-PB, Brasil 2. Medical student at the Nova Esperança Faculty of Medicine, João Pessoa-PB, Brasil 3. Doctorate; Professor and researcher at the University Center of João Pessoa - Unipê; President Director of the Nikola Tesla Research Center, João Pessoa-PB, Brasil 4. Doctorate; Neonatology Pediatrician at the Cândida Vargas Maternity, João Pessoa-PB, Brasil

http://dx.doi.org/10.1590/1806-9282.65.6.909

\section{SUMMARY}

INTRODUCTION: The Zika virus (ZIKV) is an arbovirus isolated for the first time in 1947 and transmitted to humans by the Aedes aegypti mosquito. In Brasil, it was first detected in May 2015. Since then, ZIKV has been identified as the etiological agent of acute exanthematous disease in Brasil, and Neuropediatricians of the Recife warned about an epidemic of microcephaly, and the Brazilian Ministry of Health confirmed the association between ZIKV and Congenital malformations and neurological syndromes. The eye, as an extension of the developing brain, has been examined in patients with microcephaly and maternal history of ZIKV infection.

METHODS: Twenty newborn patients with microcephaly, whose mothers had presumed Zika virus during pregnancy, were analyzed through medical records. The nonparametric chi-square statistic was used to verify the association between head circumference and ocular alteration at a significance level of 0.0001.

RESULTS: The significance of $P=0.000$ in the value of non-parametric chi-square statistics was lower than the value of $\alpha=0.0001$, demonstrating that, at a level of 0.0001 , there is an association between head circumference and ocular alteration.

CONCLUSION: Although the knowledge of the natural evolution of the disease is still scarce, the current evidence is strong enough to establish a causal relationship between ZIKV infection during pregnancy and the increased incidence of the microcephaly and serious eye alterations that lead to the severe lower vision of these children.

KEYWORDS: Zika virus. Pregnancy. Microcephaly. Eye manifestations.

The Zika virus is an arbovirus that was isolated for the first time in non-human primates in Uganda, in the Zika forest, in 1947, through a network for sylvatic yellow fever monitoring, and is transmitted to humans through the bite of Aedes aegypti. In Brasil, it was first identified by molecular biology in May 2015, and since then, his presence was confirmed in 18 Brazilian states, initially in the Northeast region ${ }^{1-3}$.
Since then, the Zika virus (ZIKV) was identified as the etiologic agent of the acute exanthematous disease in Brasil, and from October of the same year, neuropediatricians in Recife (Pernambuco) warned about an epidemic of microcephaly with peculiar radiographic changes suggestive of congenital infection ${ }^{4}$. The Ministry of Health of Brasil confirmed the relationship between the Zika virus 
and microcephaly and issued an epidemiological alert about the association between the viral infection, congenital malformations, and neurological syndromes ${ }^{1.5}$.

Microcephaly is not a disease in itself, but a sign of destruction or deficit of brain growth, with a congenital malformation defined as a head much smaller in size than those of other babies of the same age and $\operatorname{sex}^{4.6}$.

The sequelae of microcephaly depend on its etiology and the age at which the event occurred, the earlier the infection, the more serious are the anomalies of the central nervous system (CNS) ${ }^{4.6}$.

The eye, as an extension of the developing brain, has been examined in patients with microcephaly and a maternal history of infection by Zika virus. In $55 \%$ of patients with Zika virus infection, in the 20152016 Brazilian epidemic, there were central anomalies in the retina and other ocular alterations ${ }^{4,7-11}$. These neurodevelopmental defects, associated with Zika infections, are grouped into what is called Zika virus syndrome ${ }^{12}$.

The retinal changes caused by Zika virus infection usually involve the macula, with injuries ranging from mild pigmentation alterations to retinal atrophy ${ }^{13-16}$.

The present study describes the profile of children with microcephaly, born in a maternity hospital of reference in João Pessoa, whose mothers presumably had a Zika infection during pregnancy, and the association between ocular alterations and head circumference, in addition to a review of the literature on the subject.

\section{METHODS}

We analyzed, by means of a medical chart, 20 newborn patients with microcephaly, whose mothers presumably had a Zika virus infection during pregnancy. This study was carried out in a maternity hospital of reference in Grande João Pessoa-PB, and we also performed a bibliographic search in the SciELO, Lilacs, and Medline databases.

The data analysis was performed from the descriptive statistics, with mean, standard deviation, median, amplitude, confidence interval, minimum and maximum values for the continuous variable of head circumference. The nonparametric Chi-square statistics were used to verify the association between head circumference and ocular alteration, at a significance level of 0.0001. The data were tabulated and analyzed using SPSS software (Statistical Package for the Social Sciences).

\section{RESULTS}

Of the 20 newborns whose medical records were analyzed, 10 were males and 10 females, all born at term, with gestational age ranging from 37 to 40 weeks and an average weight of $2.649 \mathrm{~kg}$. Most mothers, around 70\% (14 mothers), reported the presence of a rash during pregnancy, suggesting that they might have been affected by Zika virus in the gestational period.

Of these, 11 reported it during the first trimester of pregnancy, and three in the second trimester. The head circumference ranged from $27 \mathrm{~cm}$ to $31.5 \mathrm{~cm}$ at birth, with an average of $29.5 \mathrm{~cm}$.

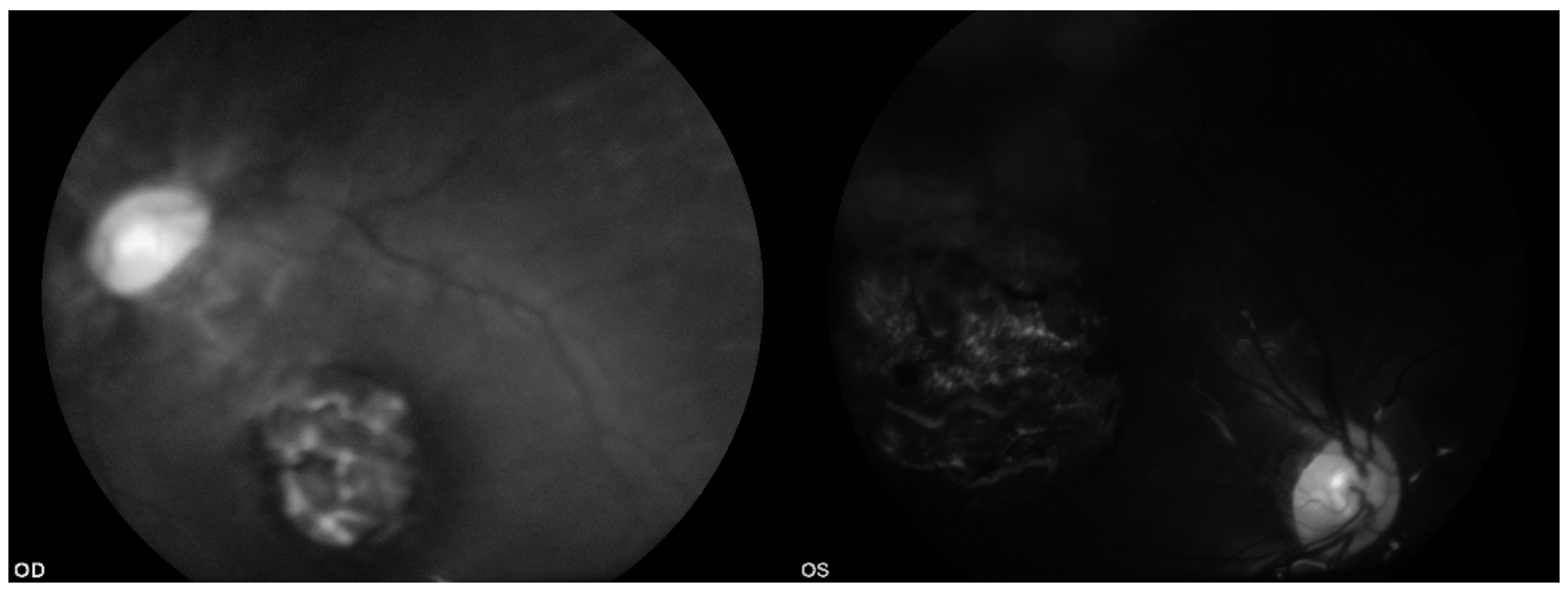

FIGURE 1 - MACULAR CHORIORETINAL ATROPHY IN BOTH EYES OF A PATIENT; THE LARGER LESION IN LOCATED ON THE LEFT EYE (LE). 
In relation to the imaging exams, all children had an ultrasound after birth, in which neurological abnormalities were observed suggesting an intrauterine infection. Of these, the most frequent was ventriculomegaly/hydrocephalus in $75 \%$ of the patients, followed by brain calcifications in $55 \%$ of them. Other changes found were cerebral hemorrhage and brain alterations, such as lissencephaly and pachygyria.

In relation to the ocular effects, these were observed in $70 \%$ of the patients, and macular atrophy was the most frequent (30\%) (Figure 1). The ocular alterations found ranged from normality to paleness and hypoplasia of the optic nerve, dispersion of retinal pigment epithelium in the macular region and chorioretinal macular atrophy (Figure 2).

According to the data in Table 1, the mean head circumference is of $29.55 \mathrm{~cm}$, with a positive or negative variation of 1.54 . The minimum value observed for the head circumference was 27 and the maximum 32. The amplitude of the head circumference, i.e., the difference between the highest and lowest values was 5 .

The significance level of $\mathrm{P}=0.000$ in the non-parametric chi-square statistic value was less than $\alpha=$ 0.0001 , showing that $\mathrm{P}<\alpha$; thus, we can conclude that, at a 0.0001 level, there is an association between the head circumference and ocular alteration.

\section{DISCUSSION}

It is known that the intrauterine period is a critical stage for the growth and development of fetal organs and tissues and that injuries suffered during this stage interfere with this process. Pregnant wom-
TABLE 1 - DESCRIPTIVE AND INFERENTIAL STATISTICS OF THE HEAD CIRCUMFERENCE.

\begin{tabular}{|c|c|c|}
\hline \multicolumn{2}{|l|}{ Average } & \multirow{2}{*}{$\begin{array}{l}29.5500 \\
28.8301\end{array}$} \\
\hline Confidence interval of $95 \%$ for the & Lower threshold & \\
\hline mean: Higher threshold & 30.2699 & \\
\hline \multicolumn{2}{|l|}{ Median } & 29.5000 \\
\hline \multicolumn{2}{|l|}{ Standard deviation } & 1.53811 \\
\hline \multicolumn{2}{|l|}{ Minimum } & 27.00 \\
\hline \multicolumn{2}{|l|}{ Maximum } & 32.00 \\
\hline \multicolumn{2}{|l|}{$\begin{array}{l}\text { Range } \\
\text { Chi-square - Sig. Assin. (2 tailed) }\end{array}$} & $\begin{array}{l}5.00 \\
0.000^{*}\end{array}$ \\
\hline
\end{tabular}

en, when infected by teratogenic etiologic agents, such as toxoplasmosis, rubella, cytomegalovirus, herpes, and syphilis, can transmit them vertically. In Brasil, the event of the epidemic of microcephaly simultaneous with the widespread Zika virus infection meant that, for the first time, a possible causal association between arbovirus infections and congenital malformations was reported and, subsequently, confirmed'.

Even though the knowledge about the natural evolution of the disease and its pathogenesis is still scarce, the current evidence is strong enough to establish a causal relationship between a Zika virus infection during pregnancy, particularly in the first trimester and not necessarily symptomatic, and the increased incidence of abortions, stillbirths, and early mortality, in addition to microcephaly and severe ocular alterations that lead to severe low vision of these children ${ }^{4}$.

The knowledge of the ocular effects of the Zika virus syndrome is based on a series of cases by many

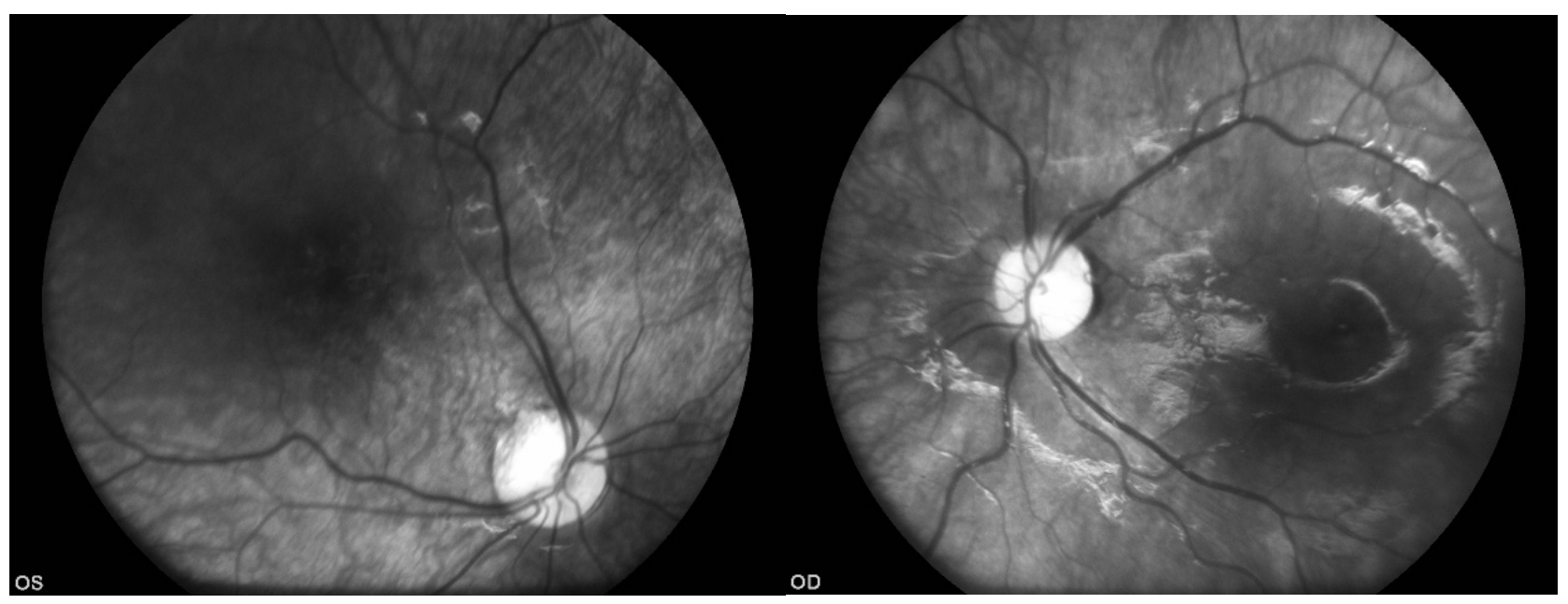

FIGURE 2 - DISPERSION OF PIGMENT EPITHELIUM IN THE MACULAR REGION OF BOTH EYES OF A NEWBORN. 
researchers, including the study group on Zika virus, which proposes to carry out ophthalmologic evaluations, not only of newborns with clinical and/or laboratory evidence of ZIKV, but also of apparently healthy children whose mothers had laboratory evidence of ZIKV infection during pregnancy or even suspected cases in endemic areas ${ }^{3.17}$.

In a case study carried out in Recife-PE, three cases of intrauterine Zika virus infection were reported, detected using a funduscopy exam of the eyes, macroscopic macular pigment, and macular chorioretinal atrophy ${ }^{5}$. In another study, 15 patients who had macular abnormalities were also described, but these have not been reported in other outbreaks of Zika virus worldwide ${ }^{2}$. Changes in the optic nerve were also observed, such as hypoplasia, paleness and an increased excavation of the optical $\operatorname{disk}^{2,5,18,19}$.

A study conducted in Colombia and Venezuela, which evaluated 43 patients between October 2015 and June 2016, showed that $12 \%$ of the cases of congenital Zika with microcephaly had anomalies of the anterior segment of the eye and $88 \%$ presented macular and optic nerve abnormalities. The visual sequelae of theses ophthalmic effects remain unknown ${ }^{20}$.

The physiopathology of the injuries presented by these infants may be related to the virus or the inflammatory response. This can result in serious brain findings (abnormal development and brain calcification), as well as ocular lesions ${ }^{2,3,5,19}$. The association between head circumference and ocular alterations observed in this study is supported by Ventura et al. ${ }^{21}$.

It is still unknown whether the ocular alterations are directly related to the effect of the ZIKV infection, microcephaly, or both. Additional studies are needed for a better understanding of this issue ${ }^{20}$.

The retinal changes caused by Zika virus infection usually involve the macula, with injuries ranging from mild pigmentation alterations to retinal atrophy ${ }^{13-16,19}$.

These exams are important both to obtain a better understanding of the disease, but also to plan strategies for visual rehabilitation in order to improve cognitive aspects ${ }^{17.18}$. Multicenter prospective studies are necessary because it will provide important data about the natural course of the disease, which will contribute to the creation of guidelines relating to the diagnosis, treatment, and follow-up for the rehabilitation and eye care of newborns with Zika virus syndrome.

The perspective of this study is to corroborate other articles in relation to the existing association between Zika, microcephaly, and ocular changes, in addition to contributing with public health policies and social measures aimed at encouraging that all newborns of mothers who presumably had a Zika infection go through ophthalmologic screenings, for early visual stimulation, in order to minimize the dependencies and the social effects caused by these changes in patients affected. In addition, this work emphasizes to the authorities that there is a need for more public and private investment for the better understanding of the disease, since the lack of financial resources for research is a key limiting factor in this process, with an impact on public health in Brasil and worldwide.

\section{RESUMO:}

INTRODUção: O vírus Zika (ZIKV) é um arbovírus isolado pela primeira vez no ano de 1947, sendo transmitido para o homem pelo mosquito Aedes aegypti. No Brasil foi detectado pela primeira vez em maio de 2015. Desde então, ZIKV foi identificado como o agente etiológico da doença exantemática aguda no Brasil, e neuropediatras do Recife deram o sinal de alerta sobre uma epidemia de microcefalia, tendo o Ministério da Saúde do Brasil confirmado a associação entre ZIKV e malformações congênitas e síndromes neurológicas. O olho, sendo uma extensão do cérebro em desenvolvimento, tem sido examinado em pacientes com microcefalia e história materna de infecção por ZIKV.

MÉTODO: Foram analisados, por meio de prontuário médico, 20 pacientes recém-nascidos, portadores de microcefalia, cujas mães tiveram presumidamente Zika vírus durante a gestação. A estatística não paramétrica Qui-Quadrado foi utilizada para verificar a associação entre perímetro cefálico e alteração ocular, no nível de significância de 0,0001.

RESULTADOS: A significância de P=0,000 no valor da estatística não paramétrica de Qui-Quadrado foi menor do que o valor de $\alpha=$ 0,0001, demonstrando que podemos afirmar que, em um nível de 0,0001, há uma associação entre o perímetro cefálico e a alteração ocular.

CONCLUSÃO: Apesar de ainda serem escassos os conhecimentos sobre a evolução natural da doença, as evidências atuais são fortes o suficiente para estabelecermos a relação causal entre a infecção pelo ZIKV durante a gravidez e o aumento da frequência da microcefalia e alterações oculares graves que levam à baixa severa da visão dessas crianças.

PALAVRAS-CHAVE: Zika vírus. Gravidez. Microcefalia. Manifestações oculares. 


\section{REFERENCES}

1. Vargas A, Saad E, Dimech GS, Santos RH, Sivini MAVC, Albuquerque LC et al. Características dos primeiros casos de microcefalia possivelmente relacionados ao vírus Zika notificados na Região Metropolitana de Recife, Pernambuco. Epidemiol Serv Saude. 2016;25(4):691-700.

2. Musso D. Zika virus transmission from French Polynesia to Brasil. Emerg Infect Dis. 2015;21(10):1887.

3. Ventura CV, Maia M, Ventura BV, Linden VV, Araújo EB, Ramos RC, et al. Ophthalmological findings in infants with microcephaly and presumable intra-uterus Zika virus infection. Arq Bras Oftalmol. 2016;79(1):1-3.

4. Ventura CV, Maia M, Bravo-Filho V, Góis AL, Belfort R Jr. Zika virus in Brasil and macular atrophy in a child with microcephaly. Lancet. 2015;387(10015):228

5. Nunes ML, Carlini CR, Marinowic D, Kalil Neto F, Fiori HH, Scotta MC, et al. Microcephaly and Zika virus: a clinical and epidemiological analysis of the current outbreak in Brasil. J Pediatr (Rio J). 2016;92(3):230-40.

6. Eickmann SH, Carvalho MDCG, Ramos RCF, Rocha MAW, van der Linden $\checkmark$, Silva PFS, et al. Síndrome da infecção congênita pelo vírus Zika. Cad Saúde Pública. 2016;32(7):e00047716.

7. Qian X, Nguyen HN, Song MM, Hadiono C, Ogden SC, Hammack C, et al. Brain-region-specific organoids using mini-bioreactors for modeling ZIKV exposure. Cell. 2016;165(5):1238-54.

8. Paula Freitas B, Oliveira Dias JR, Prazeres J, Sacramento GA, Ko Al, Maia $M$, et al. Ocular findings in infants with microcephaly associated with presumed Zika virus congenital infection in Salvador, Brasil. JAMA Ophthalmol. 2016. doi: 10.1001/jamaophthalmol.2016.0267. [Epub ahead of print]

9. Ventura CV, Fernandez MP, Gonzalez IA, Rivera-Hernandez DM, Lopez-Alberola R, Peinado M, et al. First travel-associated congenital Zika syndrome in the us: ocular and neurological findings in the absence of microcephaly. Ophthalmic Surg Lasers Imaging Retina. 2016;47(10):952-5.

10. Ventura CV, Ventura LO, Bravo-Filho V, Martins TT, Berrocal AM, Gois $\mathrm{AL}$, et al. Optical coherence tomography of retinal lesions in infants with congenital Zika syndrome. JAMA Ophthalmol. 2016;134(12):1420-7.

11. Ventura CV, Maia M, Dias N, Ventura LO, Belfort R Jr. Zika: neurological and ocular findings in infant without microcephaly. Lancet. 2016;387(10037):2502.

12. Bogas C. Brasil adota recomendações da OMS para microcefalia. [cited 2018 Nov 3]. Available from: http://combateaedes.saude.gov.br/pt/no- ticias/398-brasil-adota-recomendacao-da-oms-e-reduz-medida-para-microcefalia, 2016

13. Alvarado MG, Schwartz DA. Zika virus infection in pregnancy, microcephaly, and maternal and fetal health: what we think, what we know, and what we think we know. Arch Pathol Lab Med. 2017;141(1):26-32.

14. Araújo TVB, Rodrigues LC, Alencar Ximenes RA, Barros Miranda-Filho D, Montarroyos UR, Melo APL, et al.; investigators from the Microcephaly Epidemic Research Group; Brazilian Ministry of Health; Pan American Health Organization; Instituto de Medicina Integral Professor Fernando Figueira; State Health Department of Pernambuco. Association between Zika virus infection and microcephaly in Brasil, January to May, 2016: preliminary report of a case-control study. Lancet Infect Dis. 2016;16(12):1356-63.

15. França GV, Schuler-Faccini L, Oliveira WK, Henriques CM, Carmo EH, Pedi $V D$, et al. Congenital Zika virus syndrome in Brasil: a case series of the first 1501 livebirths with complete investigation. Lancet. 2016;388(10047):891-

16. Mlakar J, Korva M, Tul N, Popović M, Poljšak-Prijatelj M, Mraz J, et al. Zika virus associated with microcephaly. N Engl J Med. 2016;374(10):951-8.

17. Paraguassu $L$, Boadle $A$. Situação do Zika vírus no Brasil é pior que o imaginado, diz ministro da Saúde. [cited 2018 Nov 3]. Available from: https:// extra.globo.com/noticias/brasil/situacao-do-zika-virus-no-brasil-piorque-imaginado-diz-ministro-da-saude-18586668.html

18. Dias IRO, Ventura CV, Freitas BP, Prazeres |, Ventura LO, Bravo-Filho V, et al. Ocular abnormalities in congenital Zika syndrome: are the ophthalmoscopic findings "the top of the iceberg"? Prog Retin Eye Res. 2018; DOI: 10.1016/j.preteyeres.2018.04.004

19. van der Linden $V$, Pessoa A, Dobyns W, Barkovich Al, van der Linden Júnior H, Rolim Filho EL, et al. Description of 13 infants born during October 2015-January 2016 with congenital Zika virus infection without microcephaly at birth - Brasil. MMWR Morb Mortal Wkly Rep. 2016;65(47):1343-8

20. Yepez JB, Murati FA, Pettito M, Peñaranda CF, Yepez J, Maestre G, et al. Ophthalmic manifestations of congenital Zika syndrome in Colombia and Venezuela. JAMA Ophthalmol. 2017;135(5):440-5.

21. Ventura $C V$, Maia $M$, Travassos $S B$, Martins TT, Patriota F, Nunes ME, et al. Risk factors associated with the ophthalmoscopic findings identified in infants with presumed Zika virus congenital infection. JAMA Ophthalmol. 2016;134(8):912-8. 